\title{
Percentage of Carcass and Internal Organs of Japanese Quail After Given Organic Feed
}

\author{
HASAN BASRI ${ }^{1 *}$, MEILINDA PAHRIANA SULASTRI ${ }^{1}$ \\ ${ }^{1}$ Department of Biology, Faculty of Mathematics and Natural Sciences, Universitas Islam Al-Azhar Mataram \\ Jl. Unizar No. 20 Turida, Mataram, Nusa Tenggara Barat, Indonesia. 83232 \\ *Email: hasanbasri7491@gmail.com
}

Received 23 June 2019; Received in revised form 04 September 2019;

Accepted 01 December 2019; Available online 30 December 2019

\begin{abstract}
Japanese quail (Coturnix coturnix japonica) is one of the livestock sectors that is efficient in providing nutrition, both from eggs and meat. This study aims to examine the effect of the provision of standard organic feed and organic feed containing cassava leaves, turmeric powder and ginger on increasing the percentage of carcasses and internal organs Japanese quail. This study used an experimental method with a completely randomized design pattern. The test animals used were 30 females Japanese quail which were divided into 3 groups, i.e. P0: control (given commercial feed); P1: given standard organic feed (corn, soybeans, bran and fish meal); P2: given organic feed (corn, soybeans, bran, fish meal, cassava leaves, turmeric, and ginger powder). Each group was treated with 5 replications. Data obtained were analyzed using analysis of variance (ANOVA) and continued with Duncan test with a confidence of 95\% (P>0.05). The results showed that the provision of organic feed could not increase the percentage of carcass, heart, and liver, but could increase the percentage of Japanese quail gizzard.
\end{abstract}

Keywords: carcass percentage; internal organs; Japanese quail; organic feed

\section{INTRODUCTION}

Japanese quail (Coturnix coturnix japonica) is one of the livestock sectors that is efficient in providing nutrition, both from eggs and meat because that contains high animal sources (Owen \& Dike., 2013; Gecgel et al., 2015; Srinivasan, 2017). Organic quail egg contains nutrients that are good for consumption i.e. proteins of $13.02 \%$, fat $11.31 \%$, carbohydrates $0.88 \%$, and ash $0.73 \%$ (Basri et al., 2018). Quail egg also contains vitamin $A$ of $7.17(\mu \mathrm{g} / \mathrm{g})$, vitamin $\mathrm{E}$ of 59.20 $(\mu \mathrm{g} / \mathrm{g})$, omega-3 $0.44 \%$ and omega-6 $1.62 \%$ (Dudusola, 2010; Tolik et al., 2014; Tunsaringkarn et al., 2012).

Quail meat contains high protein and low fat. Quail can produce meat about $70-73 \%$ of the body weight, with the highest percentage of meat found in the chest (41\%) (Priti \& Satish, 2014). The percentage of carcasses can be used as a measure to assess livestock meat production (Greiner et al., 2003). Carcasses are affected by feed consumption, energy content, and protein. The carcass is very much influenced by the nutrient content of the ration given, especially the protein content.
According to Jeke et al. (2018) and Priti \& Satish (2014), the benefits of quail farming, i.e. at the age of six weeks the Japanese quail (Coturnix coturnix japonica) has been producing, it does not require sufficient fund, easy to maintain and can be cultivated on limited land. Another advantage is being able to produce at a young age and a short reproductive cycle.

Several types of organic ingredients that have been used as research materials in reducing cholesterol levels, namely garlic (Yeh \& Liu, 2001; Ried, 2016), ginger and turmeric (Saraswati et al., 2013). Ginger has the ability to increase appetite, strengthen the stomach, and improve digestion. This is supported by Setyanto et al. (2012) in the results of their research that there is an effect of using ginger powder on the rate of feed. Harmono \& Andoko (2005) state the stimulation of mucous membranes of the large stomach and intestine by essential oils released by the ginger rhizome, resulting in the stomach becoming empty and the chicken consuming rations. Cassava leaves contain high chlorophyll (Alsuhendra, 2004). One of chlorophyll derivate, chlorophyllin has 
higher antioxidant activity than natural chlorophyll (Lanfer-Marquez et al., 2005).

The liver has the ability to biotransform and remove the chemicals from the body $(\mathrm{Gu} \&$ Manautou, 2012; Karin \& Dhar, 2016). Curcumin works to overcome liver disorders, stimulates the production of bile which will break down fat. As a result, the digestive process is smoother. Curcumin has the potential to be antidiabetic because it can increase the work of insulin. Consumption of curcumin does not cause toxicity, because at a dose of 500 $\mathrm{mg} / \mathrm{kg}$ bodyweight does not induce polychromic erythrocytes (Negi et al., 2007).

Phytochemicals in curcumin which are important in detoxification and curcumin also have anticarcinogenic activity. Liver damage in mice induced $\mathrm{CCl} 4$ can be improved by administering turmeric root liquid extract at a dose of $50 \mathrm{mg} / \mathrm{kg}$ body weight (Sengupta et al., 2011). Curcumin has the ability to be antiinflammatory, can act as an antiviral agent, acting as an antioxidant and also a hepatoprotector (Yarru et al., 2009). Curcumin can protect DNA from damage caused by free radicals and protect hepatocytes from various poisons (Chattopadhyay et al., 2004). So that by giving organic feed can increase the activity of organs in Japanese quail (Coturnix coturnix japonica).

\section{MATERIALS AND METHODS}

The study was conducted at the Laboratory of the Faculty of Mathematics and Natural Sciences, Universitas Islam Al-Azhar Mataram. This study was an experimental study with Completely Randomized Design (CRD). The test animals used in this study were 30 female Japanese quails (Coturnix coturnix japonica) taken randomly from 65 female Japanese quails with the age of 1 day old. Selected Japanese quails were divided into 3 experimental groups. Each experimental group consisted of 5 replications. P0: Control given commercial feed; P1: Treatment given standard organic feed with a composition: (cornflour 21 $\mathrm{kg}$, soy flour $10 \mathrm{~kg}$, bran $18 \mathrm{~kg}$ and fish meal 1 $\mathrm{kg}$ ); P2: Treatment given organic food with composition (cornflour $21 \mathrm{~kg}$, soy flour $10 \mathrm{~kg}$, bran $16 \mathrm{~kg}$, fish meal $2 \mathrm{~kg}$, cassava leaves $1 \mathrm{~kg}$, turmeric powder $0,5 \mathrm{~kg}$ and ginger $0,5 \mathrm{~kg}$ ). The nutrient content of feed is based on the analysis result of the nutrition science and animal feed laboratory, Universitas Mataram presented in Table 1. At the end of the study, the internal organ of Japanese quails was taken to analysis.

Table 1. Results of laboratory analysis of feed nutrient content

\begin{tabular}{lccc}
\multicolumn{1}{c}{ Nutrition Components } & $* \mathbf{P 0}$ & $* * \mathbf{P 1}$ & $* * \mathbf{P 2}$ \\
\hline Rough Protein (\%) & $19-21$ & 15.59 & 15.18 \\
Crude fiber (\%) & 5 & 11.85 & 9.66 \\
Crude fat (\%) & 5 & 5.93 & 8.06 \\
Ash (\%) & 7 & 5.94 & 6.06 \\
Water (\%) & 13 & 11.58 & 18.38 \\
\hline
\end{tabular}

* PT. Malindo Feedmill Tbk.

**The nutrition component was analyzed at the Nutrition and Animal Feed Laboratory, Universitas Mataram (2019).

Organic Feed Making. All ingredients were mixed and stirred until blended. Materials that have been stirred evenly, weighed and packed each with a size of $1 \mathrm{~kg}$ (with the aim to facilitate the calculation of daily feed consumption). After weighing and packaging, the feed is ready for use and stored for Japanese quail food reserves.

Sterilization and acclimation to collective cages. Preparation of collective cages with an area of $1 \mathrm{~m}^{2}$. The cages and equipment were fumigated with disinfectants. Acclimation was carried out for 6 days.
Japanese quail was put into the collective cage with the formation of 10 per cages. A sugar solution with a concentration of 1 tablespoon in 1 liter of water is given to restore the Japanese quail conditions.

Giving Treatment. Giving treatment was done before Japanese quail enters the period of sexual maturity, the first provision is done when Japanese quail was 14 days old, then subsequently given every day to 50 days.

Carcass Percentage (\%). Collecting the percentage of carcass was done by comparing 
the carcass weight and live weight and then multiplied by $100 \%$ (Hamdani et al., 2017).

Percentage of internal organs (\%). Measurement of internal organs was carried out by weighing the parts that have been separated from the Japanese quail body. To get the percentage of internal organs, by comparing the weight of internal organs with slaughter weight and expressed in (\%) (Fatrah et al., 2018).

$$
\begin{aligned}
& \text { Heart percentage } \%=\frac{\text { heart weight }(\mathrm{g})}{\text { slaughter weight }(\mathrm{g})} \times 100 \% \\
& \text { Liver percentage } \%=\frac{\text { liver weight }(\mathrm{g})}{\text { slaughter weight }(\mathrm{g})} \times 100 \% \\
& \text { Gizzard percentage } \%=\frac{\text { gizzard weight }(\mathrm{g})}{\text { slaughter weight }(\mathrm{g})} \times 100 \%
\end{aligned}
$$

Data analysis. The data obtained were analyzed by variance (ANOVA), if there were significant differences followed by the Duncan test at the significance level of $95 \%$. Analysis with SPSS 16.0 for windows software.

\section{RESULT AND DISCUSSION}

The results of the analysis of the various percentages of Japanese quail carcasses and organs (Coturnix coturnix japonica) after being given organic feed are presented in Table 2.

Table 2. Results of analysis of the percentage of carcasses and organs in Japanese quail (Coturnix coturnix japonica).

\begin{tabular}{lccc}
\hline \multirow{2}{*}{ Variable } & \multicolumn{3}{c}{ Treatment } \\
\cline { 2 - 4 } & P0 & P1 & P2 \\
\hline Carcass (\%) & $60.58 \pm 4.95$ & $58.36 \pm 10.42$ & $0.91 \pm 0.18$ \\
Heart (\%) & $0.92 \pm 0.09$ & $0.95 \pm 0.19$ & $3.13 \pm 0.65$ \\
Liver (\%) & $2.51 \pm 0.29$ & $2.65 \pm 0.65$ & $4.04^{\mathrm{a}} \pm 0.75$ \\
Gizzard (\%) & $2.78^{\mathrm{b}} \pm 0.46$ & $4.18^{\mathrm{a}} \pm 0.45$ & \\
\hline
\end{tabular}

Superscripts with different lowercase letters on the same line show significant differences (P <0.05). P0: control (given commercial feed); P1: given standard organic feed (corn, soybeans, bran and fish meal); P2: given organic feed (corn, soybeans, bran, fish meal, cassava leaves, turmeric, and ginger powder).

Carcass percentage. The results of the analysis of the percentage of carcasses in Japanese quail showed no significant difference results $(\mathrm{P}>0.05)$ in the treatment $\mathrm{P} 0, \mathrm{P} 1$, and $\mathrm{P} 2$. This is due to the results of the analysis of feed consumption not significantly different (P> 0.05), thus causing no difference in the percentage of Japanese quail carcass. The highest average percentage of carcass in Japanese quail was P0 (60.58 \pm 4.95$)$, P2 (59.09 $\pm 8.33)$ and $\mathrm{P} 1(58.36 \pm 10.42)$. The results of this study are not much different from Pradikdo et al. (2016) state that the percentage of Japanese quail carcass is $58.29 \pm 1.22-62.12 \pm$ $2.93 \%$. In contrast to according to Tarigan \& Siregar (1983), Japanese quail carcasses ranged from $60 \%-75 \%$. The percentage of carcass is related to gender, age and body weight (Latorre et al., 2004; Murawska, 2012; Omar et al, 2012).

The increase in carcass is related to the increase in age and body weight. Karaoglu and Durdag (2005) stated that carcass weight depends on quail type, DOQ quality, quail maintenance management, feed quality and quantity, quail health and quail body. Generally increasing body weight was followed by a decrease in abdominal fat content which resulted in high meat production (Fouad \& ElSenousey, 2014). The increase of carcass percentage must also be supported by the nutrition of protein, carbohydrates, vitamins, minerals, and water, which must also be available in sufficient quantities. A lack of one of these nutrients results in impaired health and reduced productivity including the percentage of quail carcass. 
Heart Percentage. The results analysis of the heart percentages in Japanese quail showed no significant difference $(\mathrm{P}>0.05)$ in the treatments $\mathrm{P} 0, \mathrm{P} 1$, and $\mathrm{P} 2$. The heart is a muscular organ that plays an important role in blood circulation which is divided into four chambers, namely two ventricles and two atria. The mean percentage of heart in this study was P0 (0.92), P1 (0.95), and P2 (0.91). The results obtained are relatively the same because the maintenance system was confined or using battery cages and the activity was the same. The results of the heart percentage study were not much different from the results of Fatrah et al. (2018) where the percentage of the heart given a solution of Moringa leaves ranged from 0.88$0.95 \%$. In contrast to the results of the study by Pradikdo et al. (2016) reported the percentage of quail heart obtained ranged from 0.73 $0.80 \%$. However, the results of this study are still in accordance with the percentage of the normal heart. The size of the heart depends on sex, age, weight and animal activity. Enlargement of heart size is usually caused by the addition of heart muscle tissue caused by the activity of these animals.

Liver Percentage. The analysis results of the variance of liver percentage in Japanese quail showed no significant difference $(\mathrm{P}>$ 0.05 ) in the treatment $\mathrm{P} 0, \mathrm{P} 1$, and $\mathrm{P} 2$. This is due to the absence of toxic ingredients in both commercial and organic feed and can still be accepted by quails so that there is no swelling or damage to the liver. The highest percentage of Japanese quail liver was found in P2 (3.13 \pm 0.65), P1 (2.65 \pm 0.65) and the lowest percentage of Japanese quail liver was P0 (2.51 \pm 0.29 ). The average percentage of the liver was relatively higher than the result of Fatrah et al. (2018) that the average percentage of Japanese quail liver given a solution of Moringa leaves was $2.06 \pm 0.07-2.28 \pm 0.11 \%$. The main function of the liver is to neutralize the acidic content of the digestive tract and initiate the digestion of fat by forming an emulsion. The liver plays a role in lipid metabolism, protein, carbohydrates, and detoxification.

Gizzard Percentage. The analysis results of the percentage of gizzard in Japanese quail showed significantly different results $(\mathrm{P}<0.05)$.
The real difference was in treatment $\mathrm{P} 0$ with $\mathrm{P} 1$ and P0 with P2. The highest percentage of Japanese quail liver was found in treatment P1 $(4.18 \mathrm{a} \pm 0.45)$ and $\mathrm{P} 2(4.04 \mathrm{a} \pm 0.75)$, while the lowest average was in treatment P0 $(2.78 \mathrm{~b} \pm$ $0.46)$. In contrast to the results of the study from Fatrah et al., (2018) the percentage of Japanese quail gizzard was $(2.54 \pm 0.18) \%$. Asmawati (2015) reported where the percentage of Japanese quail gizzard obtained had an average of $2.77 \pm 0.49 \%$. Arifin and Widiastuti (2016) also reported gizzard percentages ranging from $1.90-2.34 \%$. The percentage of gizzard in treatment $\mathrm{P} 1$ and $\mathrm{P} 2$ in this study tends to be higher. This is due to treatment P1 and P2 having high crude fiber content, namely $\mathrm{P} 1$ (11.85) and P2 (9.66) \%. Table 1 shows crude fiber affects the weight and percentage of gizzard. The size of the gizzard weight was also influenced by its activity. The weight of the gizzard is influenced by crude fiber in the feed (Engberg et al., 2010; Lu et al., 2011), so that the higher the content of crude fiber in the feed, the higher the activity of the gizzard. Dharmawanti and Ari (2012) stated that the increasing weight of gizzard is not due to increasing growth, but because its function is quite heavy in grinding food ingredients into smaller particles.

\section{CONCLUSION}

Based on the results of the study, the provision of standard organic feed (P1) and organic feed containing cassava leaves, turmeric powder and ginger (P2) cannot increase the percentage of carcass, heart, and liver, but increase the percentage of Japanese quail gizzard (coturnix coturnix japonica).

\section{ACKNOWLEDGMENT}

We would like to show our gratitude to the Institute for Research and Community Service (LPPM) of Universitas Islam Al-Azhar Mataram and the Ministry of Research, Technology and Higher Education for funding this research.

\section{REFERENCES}

Alsuhendra. 2004. Daya anti-aterosklerosis znturunan klorofil dari daun singkong 
(Manihot esculenta Crantz) pada kelinci percobaan. [Disertasi]. Bogor: Institut Pertanian Bogor.

Arifin HD, and Widiastuti R. 2016. Persentase karkas dan giblet burung puyuh pengaruh supplementasi protein dan serat kasar tepung daun mengkudu dalam pakan komersial BP1O4. Journal of Animal Science and Agronomy Panca Budi. vol 1(2): 1-7.

Asmawati P. 2015. Pengaruh penambahan tepung limbah penetasan telur ayam pada pakan terhadap persentase karkas dan persentase giblet burung puyuh (Coturnixcoturnix japonica). Fakultas Peternakan. [Tesis]. Malang: Universitas Brawijaya.

Basri H, Saraswati TR, Isdadiyanto S. (2018). Hematological status of rats (Rattus norvegicus L.) in the lactation period after giving supplements organic quail eggs. Internasional Journal of Biological Research. $\quad$ vol 6(1): 1-4. http://dx.doi.org/10.14419/ijbr.v6i1.9181.

Chattopadhyay I, Biswa K, Bandyopadhyay U and Banerjee RK. 2004. Turmeric and Curcumin: biological action and medicinal applications. Review Article. Current Science, 87(1): 44-53.

Dharmawati S, and Ari JK. 2012. Pengaruh penggunaan tepung daun alang alang (Imperata cylindrica) dalam ransum terhadap kadar lemak, kolesterol karkas dan organ pencernaan itik Alabio jantan. Ziaraa'ah. vol 34(2): 150-160.

Dudusola IO. 2010. Comparative evaluation of internal and external qualities of eggs from quail and guinea fowl. International Research Journal of Plant Science. vol 1(5): 112-115.

Engberg RM, Hedemann MS, Jensen BB. 2010. The influence of grinding and pelleting of feed on the microbial composition and activity in the digestive tract of broiler chickens. British Poultry Science. vol 43(4): 569-579. doi: https://doi.org/10.1080/000716602200000 4480.

Fatrah H, Handarini R, Dihansih E. 2018. Persentase karkas dan giblet burung puyuh (Coturnix-coturnix japonica) jantan umur 35 hari yang diberi larutan daun kelor. Jurnal Pertanian, 4(2): $107-$ 114. doi: http://dx.doi.org/10.30997/jpnu.v4i2.154 2.

Fouad AM, and El-Senousey HK. 2014. Nutritional factors affecting abdominal fat deposition in poultry: A Review. Asian Australasian Journal of Animal Sciences. vol 27(7): 1057-1068. doi: https://doi.org/10.5713/ajas.2013.13702.

Gecgel U, Yilmaz I, Gurcan EK, Karasu S, Dulger GC. 2015. Comparison of fatty acid composition between female and male Japanese quail meats. Journal of Chemistry. vol 2015: 1-8 doi: https://doi.org/10.1155/2015/569746.

Greiner SP, Rouse GH, Wilson DE, Cundiff LV, Wheeler TL. 2003. Accuracy of predicting weight and percentage of beef carcass retail product using ultrasound and live animal measures. Journal of Animal Science. vol 81(2): 466-473. doi: https://doi.org/10.2527/2003.812466x.

$\mathrm{Gu}$ X, and Manautou JE. 2012. Molecular mechanisms underlying chemical liver injury. Expert reviews in molecular medicine. vol 14(2012): 1-35. doi: https://doi.org/10.1017/S14623994110021 10.

Hamdani K, Harahap MF, Hasibuan M. 2017. Pemberian tepung daun lamtoro (Leucaena leucocephala) pada ransum terhadap karkas burung puyuh (Coturnix coturnix japonica). Jurnal Peternakan. vol 1(02): 10-16. http://dx.doi.org/10.31604/jac.v1i2.240.

Harmono and Andoko A. 2005. Budidaya dan peluang bisnis jahe. Jakarta: Agromedia Pustaka.

Jeke A, Phiri C, Chitindingu K, Taru P. 2018. Ethnomedicinal use and pharmacological potential of Japanese quail (Coturnix coturnix japonica) birds meat and eggs, and its potential implications on wild quail conservation in Zimbabwe: A review. Cogent Food \& Agriculture. vol 4(1): 112. doi: https://doi.org/10.1080/23311932.2018.15 07305. 
Karaoglu M, and Durdag H. 2005. The influence of dietary probiotic (Saccharomyces cerevisiae) supplementation and different slaughter age on the performance, slaughter and carcass properties of broilers. International Journal of Poultry Science. vol 4(5): 309316.

Karin M, and Dhar D. 2016. Liver carcinogenesis: from naughty chemicals to soothing fat and the surprising role of NRF2. Carcinogenesis. vol 37(6): 541546. doi:

https://doi.org/10.1093/carcin/bgw060.

Lanfer-Marquez UM, Barros RMC, Sinnecker P. 2005. Antioxidant activity of chlorophylls and their derivates. Food Research International. vol 38 (8-9): 885-891.

https://doi.org/10.1016/j.foodres.2005.02 .012 .

Latorre MA, Lázaro R, Valencia DG, Medel P, Mateos GG. 2004. The effects of gender and slaughter weight on the growth performance, carcass traits, and meat quality characteristics of heavy pigs. Journal of animal science. vol 82(2): 526-533. doi: https://doi.org/10.2527/2004.822526x.

Lu J, Kong XL, Wang ZY, Yang HM, Zhang KN, Zou JM. 2011. Influence of whole corn feeding on the performance, digestive tract development, and nutrient retention of geese. Poultry science. vol 90(3): $587-594 . \quad$ doi: https://doi.org/10.3382/ps.2010-01054.

Murawska D. 2012. The effect of age on the growth rate of tissues and organs and the percentage content of edible and nonedible carcass components in Pekin ducks. Poultry Science. vol 91(8): 20302038. doi: https://doi.org/10.3382/ps.2011-02083.

Negi AS, Kumar JK, Luqman S, Shanker K, Gupta MM, Khanuja SPS. 2007. Recent advances in plant hepatoprotectives: a chemical and biological profile of some important leads. Medical Research Reviews. vol 28(5): 746-722. https://doi.org/10.1002/med.20115.
Omar JMA, Daya R, Ghaleb A. 2012. Effects of different forms of olive cake on the performance and carcass quality of Awassi lambs. Animal feed science and technology. vol 171(2-4): 167-172. doi: https://doi.org/10.1016/j.anifeedsci.2011. 11.002.

Owen OJ, and Dike UA. 2013. Japanese Quail (Coturnix coturnix japonica) husbandry: a means of increasing animal protein base in developing countries. Journal of Environmental Issues and Agriculture in Developing Countries. vol 5(1): 1-4.

Pradikdo BA, Sudjarwo E, Muharlien. 2016. Pengaruh jenis burung puyuh dengan pemberian pakan komersial yang berbeda terhadap persentase karkas dan organ dalam burung puyuh (Coturnixcoturnix japonica). Jurnal Ternak Tropika. vol 17(2): 23-33. https://doi.org/10.21776/ub.jtapro.2016.0 17.02.4.

Priti M, and Satish S. 2014. Quail farming: an introduction. International Journal of Life Science. vol 2(2): 190-193.

Ried K. 2016. Garlic lowers blood pressure in hypertensive individuals, regulates serum cholesterol, and stimulates immunity: an updated meta-analysis and review. The Journal of nutrition. vol 146(2): 389S396S.

doi: https://doi.org/10.3945/jn.114.202192.

Saraswati TR, Wasmen M, Damiana RE, Nastiti K. 2013. Increased egg production of japanese quail (Coturnix coturnix japonica) by improving liver function through turmeric powder supplementation. Internasional Journal of Poultry Science. vol 12(10): 601-614. https://doi.org/10.3923/ijps.2013.601.614.

Sengupta M, Sharma GD, Charaborty B. 2011. Hepatoprotective and immunomodulatory properties of aqueous extract of Curcuma longa in carbon tetra chloride intoxicated Swiss albino mice. Asian pacific. Journal of tropical biomedicine: vol 1(3): 193-199. doi: $\quad$ https://doi.org/10.1016/S22211691(11)60026-9. 
Setyanto A, Atmomarsono U, Muryani R. 2012. Pengaruh penggunaan tepung jahe emprit (Zingiber officinale var. Amarum) dalam ransum terhadap laju pakan dan kecernaan pakan ayam kampung umur 12 minggu. Animal Agriculture Journal. vol 1(1): 711-720.

Srinivasan K. 2017. Ginger rhizomes (Zingiber officinale): A spice with multiple health beneficial potentials. Pharmanutrition. vol 5(1): $18-28$. https://doi.org/10.1016/j.phanu.2017.01.0 01.

Tarigan P, and Siregar AP. 1983. Pemeliharaan Burung Puyuh. Jakarta: Direktorat Bina Produksi Peternakan.

Tolik D, Po£Awska E, Charuta A, Nowaczewski S, Cooper R. 2014. Characteristics of egg parts, chemical composition and nutritive value of Japanese quail eggs - A Review. Folia Biologica (Kraków). vol 62(2014): 287-
292.

doi:

https://doi.org/10.3409/fb62_4.287.

Tunsaringkarn T, Tungjaroenchai W, Siriwong W. 2012. Nutrient benefits of quail (Coturnix coturnix japonica) eggs. Annals. Food Science and Technology. vol 13(2): 122-131.

Yarru LP, Settivari RS, Gowda NKS, Antoniou E, Ledoux DR, Rottinghaus GE. 2009. Effects of turmeric (Curcuma longa) on the expression of hepatic genes associated with biotransformation, antioxidant, and immune systems in broiler chicks fed aflatoxin. Poultry Science. vol 88(12): 2620-2627.

https://doi.org/10.3382/ps.2009-00204.

Yeh YY., and Liu L. 2001. Cholesterollowering effect of garlic extracts and organosulfur compounds: human and animal studies. The journal of nutrition. vol 131(3): 989S-993S. doi: https://doi.org/10.1093/jn/131.3.989S. 